\title{
PERLINDUNGAN HUKUM TERHADAP JABATAN NOTARIS ATAS DUGAAN PELANGGARAN KODE ETIK DALAM PENGURUSAN HARTA WARIS (STUDI PUTUSAN MAJELIS PENGAWAS PUSAT NOTARIS NOMOR 03/MPPN/VIII/2016)
}

\author{
Michael Amsal Sumitro \\ (Mahasiswa Program S1 Fakultas Hukum Universitas Tarumanagara) \\ (E-mail: michael.amsal93@gmail.com)
}

\section{Endang Pandamdari}

(Corresponding Author)

(Dosen Hukum Jaminan Universitas Tarumanagara, Meraih Sarjana Hukum (S.H.) dari Fakultas

Hukum Universitas Indonesia (1983), Spesialis Notaris dari Universitas Indonesia (1993),

Magister Hukum (M.H.) dari Universitas Indonesia (1996), Doktor (Dr.) Hukum dari Universitas Trisakti (2011))

(E-mail: epandamdari@yahoo.com)

\begin{abstract}
Notary Is a Public Official granted authority by the State in making an Authentic Deed. On that basis, it is necessary to have legal protection for a Notary if in conducting his / her position of office sued on the alleged violation of code of ethics as it happened in Decision of Supervisory Board of Notary Center Number 03/MPPN/VIII/2016. Notary LIS is sued with alleged violation of code of ethics on the management of the heirs but the allegations according to the judges in both $M P W$ and MPPN the action does not violate the code of ethics. Based on the analysis result that referring to Article 9 paragraph (7) Notary Code of Ethics, the legal protection of the notary's office on the alleged violation of the code of ethics in the management of the permanent inheritance shall be entitled to the protection of a good name through a letter issued by the Notary Publicity Council. The qualification of a notary act can be regarded as a violation of the code of ethics only stipulated in the provisions of Article 4 of the Code of Ethics of 2015. Notary LIS is in fact violating Article 52 UUJN because in carrying out the task of handling of inheritance based on an oral testament there is still family relation. However, the MPPN is not careful that such action is not a violation of UUJN.
\end{abstract}

Keywords: Notaries, Honorary Council of Notaries, Legal Protection, Violations of the Code of Ethics, Notary Public Law 
I. Pendahuluan

\section{A. Latar Belakang}

Profesi Notaris merupakan profesi yang terhormat karena tugas dari jabatannya adalah untuk melayani kepentingan masyarakat khususnya dalam bidang hukum perdata dan sangat besar perannya bagi bangsa dan Negara, khususnya di dalam memberikan kepastian hukum, baik dalam perjanjian, kontrak, dan pengikatan lainnya, yang memberikan kepastian hukum, dengan maksud untuk membantu dan melayani masyarakat yang membutuhkan alat bukti tertulis yang bersifat otentik mengenai keadaan, perisiwa atau perbuatan hukum para penghadap. ${ }^{1)}$ Akta yang di buat oleh Notaris juga dapat menjadi alas hukum atas status harta benda, hak dan kewajiban seseorang.

Dapat dikatakan bahwa, jabatan Notaris timbul karena adanya kebutuhan masyarakat di dalam mengatur pergaulan hidup sesama individu yang membutuhkan suatu alat bukti mengenai hubungan

1 Syafran Sofyan, "Perlindungan Hukum Terhadap Profesi Notaris", (On-Line), http://www.indonesianotarycommunity.co $\mathrm{m} /$ perlindungan-hukum-terhadap-profesinotaris/, (4 Maret 2018). keperdataan di antara mereka. ${ }^{2)}$ Namun demikian, dalam menjalankan profesinya tidak jarang seorang notaris dilaporkan oleh klien ke lembaga etik notaris yaitu Majelis Pengawas Daerah karena dalam pengurusan dinilai telah melanggar kode etik notaris.

Salah satunya yaitu pengurusan harta peninggalan yang kemudian dibagikan kepada ahli waris tentu melibatkan jasa notaris. Sebelum harta dibagikan dan dibuatkan akta atau dipindahtangankan kepada ahli waris maka langkah awal yang dilakukan adalah menginventarisir daftar hartaharta yang dimiliki pewaris. Setelah keseluruhan daftar harta diketahui maka kemudian dicocokkan antara objek harta peninggalan dengan surat-surat yang ada.

Menjadi permasalahan adalah ketika notaris diberikan amanat untuk mengurus mengalihkan sejumlah harta tanpa sepengetahuan ahli waris karena keberadaannya tidak diketahui. Apalagi amanat yang disampaikan hanya secara lisan sehingga tidak ada bukti yang kuat ketika kasus ini

2) Lumban Tobing, Peraturan Jabatan Notaris, Cetakan ke-4, (Jakarta: Erlangga, 1996), hal.30. 
dipermasalahkan ke Majelis Pengawas Daerah Notaris (MPDN). Meskipun notaris tersebut memiliki hubungan saudara dengan pemberi amanat, bukti otentik berupa surat pemberian amanat sangat penting.

Digugatnya notaris dalam menjalankan jabatannya sebagaimana yang terjadi dalam kasus Putusan Nomor 03/MPPN/VIII/2016, karena notaris Lily Iswanti Sudjana (LIS) diduga menjalankan tugasnya melanggar kode etik notaris seperti: ${ }^{3)}$

1. Tidak pernah menunjukkan daftar harta-harta tidak bergerak (berupa tanah dan bangunan) milik Alm. Haryanto kepada ahli waris istri dan anaknya (Sherly Kumalawati Hardjo dan Laura Kumala Haryanto) padahal LIS telah mengambil seluruh suratsurat tanah milik Alm. Haryanto dari Euis Ernah yang diketahui sebagai istri tidak sah Alm. Haryanto.

2. Mempersulit mengambil surat-surat tanah Alm. Haryanto dan LIS tidak pernah menyerahkan suratsurat tanah tersebut melainkan kepada Rudi

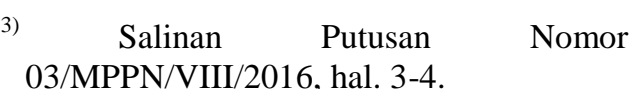

Suyatno selaku aduk kandung Alm. Haryanto.

3. Meminta secara paksa dokumen-dokumen milik ahli waris berupa copy KTP, copy akta lahir, akta nikah tanpa memberitahukan tujuan dokumen tersebut diminta, sehingga sangat patut dicurigai dokumendokumen milik ahli waris tersebut disalahgunakan untuk pengalihan tanah dan bangunan milik Alm. Haryanto lainnya tanpa seijin dan sepengetahuan ahli waris.

4. Melakukan tindakan membuat akta jual beli (AJB) tanah dan bangunan milik Alm. Haryanto yang terletak di Perumahan Pondok Cilegon Indah tanpa meminta persetujuan ahli waris.

5. Notaris LIS kembali melakukan tindakan yang tidak sesuai dengan aturan hukum dan patut diduga merupakan pelanggaran kode etik, dimana notaris LIS telah mengalihkan kembali tanah dan bangunan di Pondok Cilegon Indah tersebut dari Euis Erna kepada pihak ketiga, tanpa seijin ahli waris sah dari Alm. Haryanto.

Gugatan ahli waris yang diajukan ke MPDN Kab/Kota 
Serang Kota Cilegon maupun maupun Majelis Pengawas Pusat Notaris (MPPN) ditolak. Menyatakan tindakan notaris LIS tidak terbukti melanggar ketentuan Undang-Undang Nomor 2 Tahun 2014 tentang Perubahan Atas UndangUndang Nomor 30 Tahun 2004 tentang Jabatan Notaris dan atau Peraturan Menteri Hukum dan HAM Nomor M.02.PR.08.10 Tahun 2014 tentang Tata Cara Pengangkatan Anggota, Pemberhentian Anggota, Susunan Organisasi dan Tata Cara Pemeriksaan Majelis Pengawas Notaris.

Perbuatan Notaris yang digugat karena dinilai melanggar kode etik notaris dalam menjalankan tugasnya dan setelah proses persidangan dinyatakan tidak terbukti, maka perlu ada perlindungan hukum terhadap jabatan notaris yang diduga melakukan pelanggaran kode etik. Gugatan yang telah dilakukan oleh ahli waris jelas telah menghambat pekerjaan notaris yang bersangkutan karena harus mengorbankan waktu dan tenaga selama proses persidangan berlangsung. Padahal dalam menjalankan tugasnya notaris LIS tersebut dilakukan karena adanya amanat meskipun hanya sebatas lisan dan telah berusaha untuk membuat surat keterangan waris dan membaliknamakan harta almarhum ke ahli waris, tetapi adanya kepemilikan 2 (dua) KTP dari salah satu ahli waris sehingga proses tersebut tidak dapat dilakukan.

UUJN sebenarnya telah mengatur mengenai perlindungan Hukum bagi Notaris yang dilakukan oleh Majelis Kehormatan Notaris (MKN), pengaturan mengenai kedudukan serta bentuk perlindungan hukumnya tidak diatur secara tegas dalam suatu peraturan perundangundangan, sehingga dalam hal ini terjadi kekosongan Norma dalam penegakan Hukum bagi Notaris yang harus dilakukan oleh Majelis Kehormatan Notaris (MKN). Dalam kasus yang dialami Notaris LIS dalam putusannya tidak disebutkan pemulihan nama baiknya yang telah dituduh melanggar kode etik. Apabila dicermati ada kesalahan di pihak penggugat yang memiliki 2 (dua) KTP ganda yang mengakibatkan pembuatan surat keterangan waris tidak dapat diproses lebih lanjut.

Sebagai negara hukum, perlindungan bagi bangsa Indonesia merupakan suatu keharusan. Pasal 1 Ayat (3) Undang-Undang Dasar Negara 
Republik Indonesia (UUDNRI)

Tahun 1945 menyatakan

bahwa Indonesia adalah negara

hukum. Dengan demikian

negara menjamin hak-hak

hukum warga negaranya

dengan memberikan

perlindungan hukum dan

perlindungan hukum akan

menjadi hak bagi setiap warga negara.

Kasus di atas menurut penulis dinilai menarik untuk diteliti karena untuk melihat ada tidaknya pelanggaran kode etik yang dilakukan Notaris LIS dalam menjalankan tugasnya serta melihat bagaimana perlindungan hukum terhadap jabatan notaris dalam menjalankan tugasnya.

Berdasarkan latar belakang yang telah dijelaskan tersebut di atas, maka Penulis tertarik untuk mengkaji lebih dalam mengenai: "Perlindungan Hukum Terhadap Jabatan Notaris Atas Dugaan Pelanggaran Kode Etik Dalam Pengurusan Harta Waris (Studi Putusan Majelis Pengawas Pusat Notaris Nomor

03/MPPN/VIII/2016)".

B. Permasalahan

Berdasarkan uraian pada latar belakang masalah di atas penulis merumuskan masalah dalam penelitian sebagai berikut :

1. Bagaimana perlindungan hukum tehadap jabatan notaris atas dugaan pelanggaran kode etik dalam pengurusan harta waris?

2. Bagaimanakah kualifikasi tindakan notaris dapat dikatakan sebagai pelanggaran kode etik?

C. Metode Penelitian

1. Jenis Penelitian

Dalam penelitian ini menggunakan jenis penelitian hukum normatif. Penelitian dilakukan berdasarkan pendekatan yuridis normatif, meliputi penelitian terhadap azasazas hukum, sumber-sumber hukum, peraturan perundang-undangan yang bersifat teoritis ilmiah serta dapat menganalisa permasalahan yang dibahas. ${ }^{4)}$ Menurut Soerjono Soekanto penelitian hukum normtaif merupakan penelitian yang dilakukan dengan cara meneliti bahan pustaka atau data

\footnotetext{
4) Sri Mamuji, et.al., Metode Penelitian dan Penulisan Hukum, (Jakarta: Badan Penelitian Penerbit Fakultas Hukum Universitas Indonesia, 2005), hal.13.
} 
sekunder, ${ }^{5)} \quad$ sedangkan pengertian lain adalah suatu proses untuk menemukan suatu aturan hukum, prinsipprinsip hukum, maupun doktrin-doktrin hukum guna menjawab isu hukum yang dihadapi. ${ }^{6)}$

2. Pendekatan Penelitian

Di dalam suatu penelitian hukum terdapat beberapa pendekatan. Macam-macam pendekatanpendekatan yang digunakan di dalam penelitian hukum adalah: ${ }^{7)}$

a. Pendekatan undangundang (statute approach), yaitu pendekatan yang dilakukan dengan menelaah undangundang yang berkaitan dengan penulisan ini dan regulasi yang bersangkut paut dengan isu hukum yang sedang ditangani.

b. Pendekatan kasus (case approach), yaitu pendekatan pendekatan kasus dilakukan dengan cara melakukan telaah terhadap kasus-kasus

5) Soerjono Soekanto dan Sri Mamudji, Penelitian Hukum Normatif: Suatu Tinjauan Singkat, (Jakarta: PT RajaGrafindo Persada, 2003), hal. 13.

6) Peter Mahmud Marzuki, Penelitian Hukum, cetakan ke-11, (Jakarta: Kencana, 2011), hal.35.

7 ) Ibid., hal. 133. yang berkaitan dengan isu yang dihadapi yang telah menjadi putusan pengadilan yang telah mempunyai kekuatan hukum tetap.

c. Pendekatan historis (historical approach), yaitu pendekatan yang dilakukan dengan menelaah latar belakang apa yang dipelajari dan perkembangan pengaturan mengenai isu yang dihadapi.

d. Pendekatan komparatif (comparative approach), yaitu pendekatan yang dilakukan dengan membandingkan undang-undang suatu Negara dengan undangundang dari satu atau lebih Negara lain mengenai hal yang sama.

e. Pendekatan konseptual (conceptual approach), yaitu pendekatan yang beranjak dari pandangan-pandangan dan doktrin-doktrin yang berkembang di dalam ilmu hukum.

Pada penelitian ini menggunakan pendekatan undang-undang dan pendekatan kasus. Pendekatan undang-undang dilakukan dengan menelaah 
undang-undang yang

berkaitan dengan penulisan

ini dan regulasi yang

bersangkut paut dengan isu

hukum yang sedang

diteliti, ${ }^{8)} \quad$ yang

berhubungan dengan

perlindungan hukum

notaris terhadap gugatan

hukum pelanggaran kode

etik yang tidak terbukti

dalam persidangan (Kasus

Putusan

Nomor

03/MPPN/VIII/2016).

Pendekatan kasus

dilakukan dengan cara

melakukan telaah terhadap

kasus yang berkaitan

dengan isu yang dihadapi

yang telah menjadi putusan

pengadilan yang telah

mempunyai kekuatan

hukum tetap. ${ }^{9)}$

3. Teknik Pengumpulan Data

Bahan penelitian

merupakan kajian terhadap obyek yang berupa data penelitian. Untuk mendapatkan data yang diperlukan penelitian ini menggunakan 2 (dua) metode pengumpulan data yakni

penelitian

Kepustakaan (Library

Research). Penelitian

kepustakan ini dilakukan dengan mempelajari dan menganalisa secara sistematis buku-buku,

majalah, peraturan-

peraturan lainnya yang

berhubungan dengan materi

yang dibahas dalam

penelitian ini dan

selanjutnya menganalisa

masalah-masalah yang

dihadapi untuk menghimpun

data sekunder. Penelitian

Lapangan (Field Research),

penelitian lapangan

dilakukan untuk

mendapatkan data primer

sehubungan dengan

permasalahan dalam

penelitian dengan

melakukan mewawancarai

dengan pejabat notaris,

pejabat MPPN dan dosen

terkait yang berkompeten

dalam bidang yang sedang diteliti.

Untuk mendapatkan hasil yang objektif dan dapat dibuktikan kebenarannya serta dapat dipertanggungjawabkan

hasilnya, maka bahan-bahan hukum yang digunakan terbagi menjadi tiga kelompok, yaitu:

a. Bahan hukum primer, yaitu merupakan bahanbahan hukum yang bersifat utama dan mengikat. Bahan hukum primer ini terdiri dari

${ }^{8)}$ Loc.Cit.

${ }^{9)}$ Ibid, hal. 94 . 
peraturan perundangundangan, yaitu :

(1)Undang-Undang

Nomor 2 Tahun 2014 tentang perubahan atas Undang-Undang Nomor 30 Tahun 2004 tentang Jabatan Notaris.

(2)Kode Etik Notaris.

b. Bahan hukum sekunder, adalah bahan hukum yang berupa semua publikasitentang hukum yang bukan merupakan dokumen-dokumen resmi, yang dari bukubuku hukum, jurnal hukum, makalahmakalah hukum dan bahan dari internet yang berhubungan dengan penulisan skripsi ini.

c. Bahan hukum tersier, yaitu merupakan bahanbahan yang memberikan petunjuk maupun penjelasan terhadap bahan-bahan hukum primer dan sekunder.

4. Sifat Penelitian

Sifat dari penelitian ini adalah deskriptif analitis, yaitu suatu penelitian yang menggambarkan fakta-fakta hukum yang ada juga bertujuan untuk menjelaskan dengan melakukan analisis data yang diperoleh secara sistematis, faktual dan akurat dikaitkan dengan ketentuan-ketentuan yuridis yang terdapat dalam peraturan perundangundangan yang berkaitan dengan perlindungan hukum notaris terhadap gugatan hukum pelanggaran kode etik yang tidak terbukti dalam persidangan (Kasus Putusan Nomor 03/MPPN/VIII/2016).

5. Teknik Analisis Data

Metode analisis data yang digunakan dalam penelitian ini yaitu metode yuridis normatif, maka pengolahan data pada hakekatnya merupakan kegiatan untuk mengadakan analisa terhadap permasalahan yang akan diteliti. Teknik analisis data yang digunakan adalah teknik analisis data kualitatif, yaitu dengan mengumpulkan data, mengkualifikasikan, kemudian menghubungkan teori yang berhubungan dengan masalah dan akhirnya menarik kesimpulan untuk menentukan hasil pada penulisan penelitian ini.

II. Pembahasan 
A. Perlindungan Hukum Tehadap Jabatan Notaris Atas Dugaan Pelanggaran Kode Etik Dalam Pengurusan Harta Waris

Digugatnya notaris dalam menjalankan jabatannya sebagaimana yang terjadi dalam Putusan Nomor 03/MPPN/VIII/2016, kasus ini bermula dari adanya pengaduan atas dugaan pelanggaran etik yang dilakukan oleh Lily lswanti Sudjana (LIS), Notaris/PPAT di Kota Cilegon - Banten, yang disampaikan oleh Sherly Kumalawati Hardjo (SKH) dan Laura Kumala Haryanto (LKH) melalui Kuasa Hukumnya Hotma Sitompoel yang ditujukan kepada Majelis Pengawas Daerah (MPD) Notaris Kota Cilegon Banten. Dalam keterangannya, pengaduan dugaan pelanggaran kode etik yang dilakukan oleh SKH dan LKH mengaku sebagai istri dan anak yang sah dari Almarhum Haryanto yang telah meninggal pada tanggal 13 Juli 2013. Dengan meninggalnya Almarhum Haryanto, maka segala harta peninggalannya menjadi milik istri dan anaknya yang sah yaitu SKH dan LKH.

\begin{tabular}{lcr}
\multicolumn{1}{c}{ Notaris } & LIS & memiliki \\
hubungan & saudara & dengan \\
Almarhum & Haryanto & dan
\end{tabular}

pernah diberikan amanat secara lisan untuk mengalihkan seluruh harta peninggalannya baik yang ada dikuasai sendiri maupun yang dikuasai pihak lain. Akan tetapi, pada saat mengurus proses peralihan tersebut dilakukan Notaris/PPAT LIS tidak memberitahukan terlebih dahulu kepada ahli waris (LKH dan SKH), dan diketahui bahwa salah satu harta peninggalannya ada yang dikuasai pihak lain yang diketahui sebagai Istri simpanan Almarhum Haryanto.

Pihak LKH dan SKH meminta Notaris/PPAT LIS untuk menunjukkan isi amanat Almarhum Haryanto, namun Notaris LIS tidak dapat menunjukkan isi amanat yang dimaksud karena dilakukan secara lisan. Tindakan Notaris/PPAT LIS yang tidak pernah menunjukkan daftar harta-harta yang milik Almarhum Haryanto padahal seluruh surat-surat tanah dan bangunan tersebut telah dikuasainya.

Menurut LKH dan SKH ada beberapa tindakan yang dinilai merugikan kepentingan ahli waris dan sangat patut diduga sebagai pelanggaran kode etik karena, Notaris/PPAT LIS tidak pernah 
menunjukkan daftar harta-harta tidak bergerak (berupa tanah dan bangunan) milik Almarhum Haryanto kepada ahli waris warisnya, ahli waris baru menerima sebagian dari surat-surat tanah milik Almarhum Haryanto, LKH dan SKH selalu dipersulit oleh Notaris/PPAT LIS saat akan mengambil surta-surat tanah Almarhum Haryanto dimana Notaris/PPAT LIS tidak pernah menyerahkan surat-surat tanah tersebut kepada LKH dan SKH melainkan kepada Rudi Suyanto (saudara kandung Almarhum Haryanto), notaris LIS juga pernah meminta secara paksa dokumendokumen milik para LKH dan SKH berupa copy KTP, copy Akta lahir, Akta Nikah, tanpa memberitahukan tujuan dokumen tersebut diminta, notaris/PPAT LIS melakukan tindakan yang tidak sesuai aturan hukum dan patut diduga merupakan pelanggaran kode etik karena mengalihkan kembali tanah dan bangunan di Pondok Cilegon Indah tersebut dari Euis Erna kepada phak ketiga, tanpa seijin ahli waris yang sah dari Almarhum Haryanto.

Berdasarkan hal tersebut, SKH mohon agar Majelis Pengawas Daerah Notanis Cilegon Banten dapat segera memanggil, memeriksa, mengadili dan menjatuhkan tindakan tegas terhadap Notaris/PPAT LIS selaku PPAT di Kota Cilegon Banten yang diduga telah melakukan tindakan pelanggaran kode etik selaku PPAT.

Gugatan ahli waris yang diajukan ke MPDN Kab/Kota Serang Kota Cilegon maupun maupun Majelis Pengawas Pusat Notaris (MPPN) ditolak. Menyatakan tindakan notaris LIS tidak terbukti melanggar ketentuan Undang-Undang Nomor 2 Tahun 2014 tentang Perubahan Atas UndangUndang Nomor 30 Tahun 2004 tentang Jabatan Notaris dan atau Peraturan Menteri Hukum dan HAM Nomor M.02.PR.08.10 Tahun 2014 tentang Tata Cara Pengangkatan Anggota, Pemberhentian Anggota, Susunan Organisasi dan Tata Cara Pemeriksaan Majelis Pengawas Notaris.

Adanya pengaduan dari LKH dan SKH terhadap Notaris/PPAT LIS, maka Majelis Pengawas Daerah Notaris Kabupaten/Kota Serang dan Kota Cilegon telah memeriksa Notaris/PPAT LIS yang dituangkan dalam Berita Acara Pemeriksaan Nomor 22/BAP/MPDN Kab/Kota 
Serang Kota Cliegon 05.15 tanggal 12 April 2015.

Majelis Pengawas Daerah

Notaris Kab. Serang/Kota Cilegon memanggil

Notaris/PPAT LIS melalul surat Nomor

UM.MPD.Kab/Kota SRG-

CLG.05.15-30 tanggal 8 Mei 2015 perihal panggilan.

Majelis Pengawas Daerah

Notaris Kab. Serang/Kota Cilegon dalam rapat pleno hari selasa tanggal 12 Mel 2015 telah membentuk Tim Majelis Pemeriksa Notaris dengan keputusan Ketua Majelis Nomor M.55.MPDN Kab. Serang dan Kota Cilegon 05.15-20.

Majelis Pemeriksa Daerah Notaris Kabupaten/Kota Serang dan Kota Cliegon dalam sidang pemeriksaan pada hari Selasa tanggal 12 Mei 2015 diperoleh keterangan Notaris/PPAT LIS (Notaris/PPAT LIS) menyatakan tidak pernah membuat amanat maupun mencatat dalam jabatan saya selaku Nofaris/PPAT untuk mengalihkan sejumlah harta milik Almarhum Haryanto sebagaimana yang dituduhkan kepada saya, tetapi yang benar adalah saya selaku pribadi dan selaku saudara sepupu dari Almarhum Haryanto dirninta untuk mengambli sertifikat dari
Euis Erna yang selanjutnya diserahkan kepada anak almarhum Maureen Yoanita Haryanto selaku ahli waris dan hal tersebut telah saya laksanakan.

Notaris/PPAT LIS tidak pernah membuat Akta amanat, melainkan Notaris/PPAT LIS hanya mendapatkan amanat secara lisan dari Almarhum Hanyanto semasa hidupnya dan Notaris/PPAT LIS tidak pernah membuat Akta Notaris yang berkitan dengan hal tersebut yang dibuat adalah berupa surat keterangan dibawah tangan yang menyatakan telah menerima dokumen dari Euis Erna berdasarkan amanat Almarhum Haryanto sebagaimana tanda terima yang dibuat dengan tulisan tangan dan diserahkan kepada Notaris/PPAT LIS. Selain itu, terdapat pengalihan rumah di Jl. Pondok Cilegon Indah Blok A 18 Kel. Kedaleman Kec. Cibeber Banten bukan merupakan kewenangan Majelis Pengawas Notaris dikarenakan untuk jual beli tersebut yang bersangkutan (Notaris/PPAT LIS) bertindak selaku Pejabat Pembuat Akta Tanah (PPAT) bukan sebagai Notaris.

Majelis Pengawas Wiiayah Notaris Provinsi Banten akan 
mempertimbangkan apakah pengaduan yang diajukan oleh SKH dan LKH sudah sesuai dengan Peraturan Menteri Hukum dan HAM No. M.02.PR.08.10 Tahun 2004 tersebut.

Berdasarkan Berita Acara Pemeriksaan Majelis

Pemeriksa Daerah Notaris Kabupaten Serang dan Kota Cilegon Nomor 35/BAP/MPDN Kab. Serang dan Kota Cilegon 05.15 tanggai 5 Juni 2015 dan memperhatikan pasal-pasal Undang-Undang Nomor 2 Tahun $2014 \quad$ Tentang Perubahan Atas UndangUndang Nomor 30 Tahun 2004 tentang Jabatan Notaris, khususnya Pasal 1, Pasal 4, Pasal 67 Jo. Pasal 25 dan Pasal 27 Peraturan Menteri Hukum dan Hak Asasi Manusia Nomor M.02.PR.08.10 Tahun 2004 tentang Tata Cara Pengangkatan Anggota, Pemberhentian Anggota, Susunan Organisasi, Tata Kerja dan Tata Cara Pemeriksaan Majelis Pengawas Notaris.

SKH dan LKH menyatakan keberatan atas pertimbangan dari Majelis Wilayah yang menyatakan dalam pertimbangan hukumnya "bahwa Notaris/PPAT LIS tidak pernah membuat akta amanat, melainkan Notaris/PPAT LIS hanya mendapatkan amanat secara lisan dari Almarhum Haryanto semasa hidupnya" adalah pertimbangan yang keliru karena, pertimbangan hukum MPW tersebut adalah pertimbangan hukum yang keliru, karena tidak didasarkan pada fakta-fakta hukum yang timbul dalam persidangan.

Majelis Wiiayah tidak mempertimbangkan dan mengesampingkan fakta hukum bahwa Notaris/PPAT LIS telah melakukan pelanggaran hukum selaku Notaris karena dengan sengaja dan tanpa hak, meminta dokumen-dokumen tanapa pernah diketahui oieh para klien kami, tujuan dokumendokumen tersebut diminta. Kami meyakini dokumendokumen tersebut telah dipergunakan untuk mengalihkan harta-harta Almarhum Haryanto Iainnya tanpa sepengetahuan para klien kami.

Oleh karena itu, sepatutnya berdasarkan fakta tersebut demi hukum MPW harus menyatakan Notaris/PPAT LIS telah melanggar kode Etik Notaris dan seharusnya melaporkan sendiri Notaris/PPAT LIS 
kepada pihak kepolisian atas dugaan tindak pidana penggelapan, penipuan dan tindak pidana pemalsuan.

SKH dan LKH keberatan terhadap Putusan Majelis Pengawas Wiiayah yang tidak memepertimbangkan

pengaduan yang diajukan terkait sikap dan tingkah laku Notaris/PPAT LIS Teriapor yang tidak mencerminkan sikap seorang Notaris yang profesional.

UUJN sebenarnya telah mengatur mengenai perlindungan Hukum bagi Notaris yang dilakukan oleh Majelis Kehormatan Notaris $(\mathrm{MKN})$, pengaturan mengenai kedudukan serta bentuk perlindungan hukumnya tidak diatur secara tegas dalam suatu peraturan perundangundangan, sehingga dalam hal ini terjadi kekosongan Norma dalam penegakan Hukum bagi Notaris yang harus dilakukan oleh Majelis Kehormatan Notaris (MKN). Dalam kasus yang dialami Notaris LIS dalam putusannya tidak disebutkan pemulihan nama baiknya yang telah dituduh melanggar kode etik. Apabila dicermati ada kesalahan di pihak penggugat yang memiliki 2 (dua) KTP ganda yang mengakibatkan pembuatan surat keterangan waris tidak dapat diproses lebih lanjut.

Sebagai negara hukum, perlindungan bagi bangsa Indonesia merupakan suatu keharusan. Pasal 1 Ayat (3) Undang-Undang Dasar Negara Republik Indonesia (UUDNRI) Tahun 1945 menyatakan bahwa Indonesia adalah negara hukum. Dengan demikian negara menjamin hak-hak hukum warga negaranya dengan memberikan perlindungan hukum dan perlindungan hukum akan menjadi hak bagi setiap warga negara.

Ruang lingkup kewenangan notaris adalah di bidang hukum perdata dalam rangka menciptakan kepastian hukum melalui alat bukti akta otentik. Eksistensi notaris sebagai Pejabat Umum didasarkan atas UUJN yang menetapkan rambu-rambu bagi penggerak langkah seorang notaris. Adanya kewajiban kepribadian yang baik dan tuntutan untuk menjunjung tinggi martabat jabatan notaris, dengan demikian dalam pelaksanaan jabatannya notaris harus memiliki pengetahuan secara teoritis dan pengalaman secara teknis, tetapi juga harus ditambah dengan memiliki tanggung jawab etika hukum yang tinggi berupa nilai-nilai 
atau ukuran-ukuran etika, penghayatan terhadap keluhuran dan tugas jabatannya, serta integritas dan moral yang baik.

Demikian pula dengan eksistensi jabatan Notaris, khususnya yang terkait dengan persoalan perlindungan jabatan. Notaris adalah pejabat umum yang mendapatkan kuasa dari pemerintah untuk mengesahkan dan menyaksikan berbagai surat perjanjian, surat wasiat, akta, dan lain-lain. Jabatan notaris diatur UUJN yang merupakan produk hukum yang dimaksudkan untuk memberikan kepastian dan perlindungan hukum bagi Notaris dalam menjalankan profesinya sebagai pejabat pembuat akta otentik. Oleh karena itu di dalam UUJN memuat aturan hukum yang salah satunya adalah bentuk perlindungan hukum bagi Notaris.

Profesi Notaris ini dilindungi oleh Majelis Kehormatan Notaris (MKN), namun MKN hanya memiliki peran melindungi profesi Notaris bukan personal Notaris. Dengan demikian, ketika Notaris melakukan atau diduga melakukan suatu tindak pidana yang tidak ada kaitannya dengan tugas jabatan Notaris, maka Penyidik tidak perlu meminta persetujuan MKN untuk memeriksanya. Sebaliknya, jika MKN Wilayah (MKNW) menerima permohonan persetujuan pemeriksaan Notaris atas dugaan tindak pidana di luar pelaksanaan tugas jabatan Notaris, maka MKNW harus menolaknya dengan alasan "tidak berwenang" memberikan persetujuan atau penolakan pemeriksaan atas kasus tersebut. Oleh karena itu, Notaris harus memiliki Integritas moral yang baik, ketelitian dan ketrampilan yang baik dalam membuat akta otentik yang sesuai dalam peraturan notaris. Jika akta otentik tersebut sudah sesuai dengan peraturan UUJN, maka Notaris tidak perlu takut jika dipanggil kepolisian untuk dimintai keterangan. Hal ini justru dapat membantu kepolisian dalam menegakkan hukum di Indonesia.

Berkaitan dengan masalah digugatnya notaris karena dinilai telah melanggar ketentuan kode etik notaris, namun dalam fakta di persidangan dinyatakan tidak terbukti, notaris berhak mendapatkan perlindungan hukum. Perlindungan hukum merupakan unsur yang harus ada dalam suatu negara. Setiap pembentukan negara pasti di 
dalamnya ada hukum untuk mengatur warga negaranya. Dalam suatu negara, terdapat hubungan antara negara dengan warga negaranya. Hubungan inilah yang melahirkan hak dan kewajiban. Perlindungan hukum akan menjadi hak bagi warga negara, namun di sisi lain perlindungan hukum menjadi kewajiban bagi negara.

Negara wajib memberikan perlindungan hukum bagi warga negaranya, sebagaimana tercantum dalam UndangUndang Dasar Negara Republik Indonesia Tahun 1945 Pasal 1 ayat (3) yang berbunyi : "Indonesia adalah Negara hukum". Perlindungan hukum merupakan suatu perlindungan yang diberikan terhadap subyek hukum (dari tindakan sewenang-wenang seseorang) dalam bentuk perangkat hukum baik yang bersifat preventif maupun yang bersifat represif, baik yang tertulis maupun tidak tertulis. ${ }^{10)}$

Keberadaan lembaga Notaris dilandasi oleh kebutuhan masyarakat dalam membuat akta otentik sebagai suatu alat bukti yang mengikat. Peran Notaris dalam memberikan pelayanan kepentingan umum tersebut adalah memberikan pelayanan dalam pembuatan akta dan tugas-tugas lain yang memerlukan jasa Notaris. Akta yang diterbitkan oleh Notaris memberikan jaminan kepastian hukum bagi masyarakat. Notaris mempunyai peran serta dalam menjalankan profesi hukum yang tidak dapat dilepaskan dari persoalanpersoalan mendasar yang berkaitan dengan fungsi serta peranan hukum itu sendiri.

Notaris perlu mendapatkan perlindungan dalam menjalankan tugasnya jika dalam keadaan diperlakukan tidak adil atau jika dalam bahaya. UUJN telah menempatkan Notaris sebagai pejabat umum, yang menjalankan tugas sebagai jabatan, karena itu perlu mendapatkan perlindungan hukum adalah Notaris sebagai jabatan, bukan Notaris sebagai pribadi. Perlindungan hukum atas hak Notaris merupakan hasil transformasi kepentingan yang dilakukan melalui proses legislasi dalam menjaga pembentuk hukum atau parlemen, sehingga hak Notaris dapat dihormati, atau dilindungi dan dipatuhi.

10) Phillipus M. Hadjon, Perlindungan Hukum Bagi Rakyat Indonesia, (Surabaya: PT. Bina Ilmu, 1987), hal.2. 
Menurut Gunawan Djajaputra, ${ }^{11)}$ apabila terdapat notaris/PPAT yang dituduh melanggar kode etik namun tidak terbukti di persidangan kode etik, maka pihak yang menuduh jika diperlukan bisa melalui pemrohonan maaf. Dengan permohonan maaf tersebut sekiranya mendapat pemulihan nama baik notaris yang bersangkutan. Oleh karena itu, disarankan sebelum membuat gugatan atas tudahan pelanggaran kode etik terhadap notaris, hendaknya pihak-pihak yang merasa jika dirugikan oleh notaris sebelum melangkah ke ranah pengadilan harus diklarifikasi terlebih dahulu ke Majelis Pengawas Daerah.

Hal yang sama juga dikemukakan oleh Edward S. Wiryomartani, ${ }^{12)}$ notaris dalam menjalan pekerjannya harus tetap dilindungi. Apabila notaris yang dituduh melanggar kode etik namun tidak terbukti dalam proses persidangan, maka bentuk perlindungannya dapat dilihat dalam Pasal 9 Ayat (7) Kode Etik Notaris Tahun 2015 yang menyatakan

11) Wawancara dengan Dr. Gunawan Djajaputra, S.H., M.H., selaku dosen dan notaris, Gedung Blok M. Universitas Tarumanagara, Jakarta, 25 April 2018.

12) Wawancara dengan Notaris Edward S. Wiryomartani, S.H., M.H., selaku Notaris/PPAT di Tangerang, 4 Mei 2018. bahwa apabila anggota yang bersangkutan tidak terbukti melakukan pelanggaran, maka anggota tersebut dipulihkan namanya dengan Surat Keputusan Dewan Kehormatan yang memeriksanya. Notaris tetap berhak mendapatkan perlindungan dalam setiap menjalankan tugasnya baik dalam kasus perdata maupun pidana sebagaimana diatur dalam UUJN dan Kode Etik Notaris. Dengan demikian, dapat dikatakan bahwa perlindungan hukum notaris dalam menjalankan jabatannya baik dugaan melanggar kode etik maupun terlibat dalam kasus pidana tetap berhak mendapatkan perlindungan.

B. Kualifikasi Tindakan Notaris Dapat Dikatakan Sebagai Pelanggaran Kode Etik

Dalam UUJN diatur bahwa ketika Notaris dalam menjalankan tugas jabatannya terbukti melakukan pelanggaran, maka Notaris dapat dikenai atau dijatuhi sanksi, berupa sanksi perdata, administrasi, dan Kode Etik jabatan Notaris, dimana sanksisanksi tersebut telah diatur sedemikian rupa dalam UUJN dan Kode Etik jabatan Notaris sedangkan sanksi pidana terhadap Notaris tidak diatur dalam UUJN maupun Kode 
Etik. Tujuan dari dibuatnya kode etik, dalam hal ini adalah Kode Etik Notaris, pada intinya adalah untuk menjaga kehormatan dan keluhuran martabat jabatan Notaris. ${ }^{13)}$

Kedudukan Kode Etik bagi Notaris, yang pertama karena sifat dan hakekat dari pekerjaan Notaris yang sangat berorientasi pada legalisasi, sehingga dapat menjadi fundamen Hukum utama tentang status harta benda, hak dan kewajiban seorang Penghadap yang menggunakan jasa Notaris tersebut. Kedua, agar tidak terjadi ketidakadilan sebagai akibat dari pemberian status harta benda, hak dan kewajiban yang tidak sesuai dengan kaidah dan prinsipprinsip hukum dan keadilan, sehingga dapat mengacaukan ketertiban umum dan juga mengacaukan hak-hak pribadi dari masyarakat pencari keadilan, maka bagi dunia Notaris sangat diperlukan juga suatu Kode Etik Profesi yang baik dan modern. ${ }^{14}$ Tujuan lainnya dari pengawasan

13) Abdul Ghofur Anshori, Lembaga Kenotariatan Indonesia, Prespektif Hukum dan Etika, (Yogyakarta: UII Press, 2009), hal. 34.

14) Munir Fuady, Profesi Mulia (Etika Profesi Hukum bagi Hakim, Jaksa, Advokat, Notaris, Kurator dan Pengurus), (Bandung: PT. Citra Aditya Bakti, 2005), hal. 133. terhadap Notaris adalah guna menjamin pengamanan dari kepentingan umum terhadap para Notaris yang menjalankan jabatannya secara tidak bertanggung jawab dan tidak mengindahkan nilainilai dan ukuran-ukuran etika serta melalaikan keluhuran dari martabat dan tugas jabatannya.

Kode etik profesi Notaris, disusun oleh organisasi profesi Notaris, Ikatan Notaris Indonesia (I.N.I). Pasal 1 angka (2) Kode Etik Notaris Ikatan Notaris Indonesia (I.N.I) menjabarkan bahwa Kode Etik Notaris dan untuk selanjutnya akan disebut kode etik adalah seluruh kaedah moral yang ditentukan oleh Perkumpulan Ikatan Notaris Indonesia yang selanjutnya akan disebut "Perkumpulan" berdasarkan keputusan Kongres Perkumpulan dan/atau yang ditentukan oleh dan diatur dalam peraturan PerundangUndangan yang mengatur tentang hal itu dan berlaku bagi serta wajib ditaati oleh setiap dan semua anggota perkumpulan dan semua orang yang menjalankan tugas jabatan sebagai Notaris, termasuk di dalamnya para Pejabat Sementara Notaris, Notaris Pengganti dan Notaris Pengganti Khusus. Kode etik Notaris merupakan seluruh 
kaedah moral yang menjadi pedoman dalam menjalankan jabatan notaris, memuat kewajiban, larangan dan pengecualian bagi notaris dalam pelaksanaan jabatannya.

Berkaitan dengan hal demikian, maka notaris diminta agar dapat menjalankan profesinya dengan profesional, dengan motivasi dan orientasi pada keterampilan intelektual serta berargumentasi secara rasional dan kritis serta menjunjung tinggi nilai-nilai moral. Selain itu, notaris juga harus melihat batasan-batasan pihak-pihak mana saja yang dilarang oleh notaris dalam membuat akta.

Tindakan notaris sangat terikat dengan kode etik notaris dan UUJN yang mengatur larangan-larangan tertentu dalam menjalankan jabatannya. Mengacu pada perubahan ketentuan Kode Etik Notaris kongres luar biasa Ikatan Notaris Indonesia di Banten pada tanggal 29-30 Mei 2015, larangan yang termuat dalam Pasal 4 Kode Etik, yaitu:

1. Mempunyai lebih dari 1 (satu) kantor, baik kantor cabang ataupun kantor perwakilan;

2. Memasang papan nama dan/atau tulisan yang berbunyi: Notaris/Kantor Notaris" di luar lingkungan kantor;

3. Melakukan publikasi atau promosi diri, baik sendiri maupun secara bersamasama, dengan mencantumkan nama dan jabatannya, menggunakan sarana media cetak dan/atau elektronik, dalam bentuk: iklan, ucapan selamat, ucapan belasungkawa, ucapan terima kasih, kegiatan pemasaran, dan kegatan sponsor baik dalam bidang sosial, keagamaan, maupun olah raga.

4. Bekerja sama dengan biro jasa/orang/Badan Hukum yang pada hakekatnya bertindak sebagai perantara untuk mencari atau mendapatkan klien;

5. Menandatangani akta yang proses pembuatannya telah dipersiapkan oleh pihak lain;

6. Mengirimkan minuta kepada klien untuk ditandatangani;

7. Berusaha atau berupaya dengan jalan apapun, agar seseorang berpindah dari Notaris lain kepadanya, baik upaya itu ditujukan langsung kepada klien yang bersangkutan maupun melalui perantaraan orang lain; 
8. Melakukan pemaksaan kepada klien dengan cara menahan

dokumendokumen yang telah diserahkan dan/atau melakukan tekanan psikologis dengan maksud agar klien tersebut tetap membuat akta padanya;

9. Melakukan usaha-usaha, baik langsung maupun d'dak langsung yang menjurus ke arah dmbuinya persaingan yang tidak sehat dengan sesama rekan Notaris;

10. Menetapkan honorarium yang harus dibayar oleh klien dalam jumlah yang lebih rendah dari honorarium yang telah ditetapkan Perkumpulan;

11. Mempekerjakan dengan sengaja orang yang masih berstatus karyawan kantor Notaris lain tanpa persetujuan terlebih dahulu dari Notaris yang bersangkutan, termasuk menerima pekerjaan dari karyawan kantor Notaris lain;

12. Menjelekkan dan/atau mempersalahkan rekan Notaris atau akta yang dibuat olehnya. Dalam hal seorang Notaris menghadapi dan/atau menemukan suatu akta yang dibuat oleh rekan sejawat yang ternyata di dalamnya terdapat kesalahan-kesalahan yang serius dan/atau membahayakan klien, maka Notaris tersebut wajib memberitahukan kepada rekan sejawat yang bersangkutan atas kesalahan yang dibuatnya dengan cara yang tidak bersifat menggurui, melainkan untuk mencegah timbulnya halhal yang tidak diinginkan terhadap klien yang bersangkutan ataupun rekan sejawat tersebut

13. Tidak melakukan Kewajiban dan melakukan Pelanggaran terhadap Larangan sebagaimana dimaksud dalam Kode Etik dengan menggunakan media etektronik, termasuk namun tidak terbatas dengan menggunakan internet dan media sosial;

14. Membentuk kelompok sesama rekan sejawat yang bersifat eksklusif dengan tujuan untuk melayani kepentingan suatu instansi atau lembaga, apalagi menutup kemungkinan bagi Notaris lain untuk berpartisipasi;

15. Menggunakan dan mencantumkan gelar yang tidak sesuai dengan 
peraturan perundangundangan yang berlaku;

16. Membuat akta melebihi batas kewajaran yang batas jumlahnya ditentukan oleh Dewan Kehormatan;

17. Mengikuti pelelangan untuk mendapatkan pekerjaan/pembuatan akta. Dalam Pasal 17 Ayat (1) UUJN juga mengatur laranganlarangan notaris. Larangan bagi Notaris merupakan suatu aturan yang memerintahkan kepada Notaris untuk tidak melakukan sesuatu yang bertentangan dengan peraturan perundang-undangan yang berlaku. Larangan-larangan tersebut menegaskan bahwa:

1. Menjalankan jabatan di luar wilayah jabatannya;

2. Meninggalkan wilayah jabatannya lebih dari 7 (tujuh) hari kerja berturutturut tanpa alasan yang sah;

3. Merangkap sebagai pegawai negeri;

4. Merangkap jabatan sebagai pejabat negara;

5. Merangkap jabatan sebagai advokat;

6. Merangkap jabatan sebagai pemimpin atau pegawai badan usaha milik negara, badan usaha milik daerah atau badan usaha swasta;

7. Merangkap jabatan sebagai Pejabat Pembuat Akta Tanah dan/atau Pejabat
Lelang Kelas II di luar tempat kedudukan Notaris;

8. Menjadi Notaris Pengganti; atau

9. Melakukan pekerjaan lain yang bertentangan dengan norma agama, kesusilaan, atau kepatutan yang dapat mempengaruhi kehormatan dan martabat jabatan Notaris.

Berdasarkan laranganlarangan notaris tersebut di atas, maka apabila dikaitkan dengan kasus dugaan pelanggaran etik pada perkara Putusan Majelis Pengawas Pusat Notaris Nomor 03/MPPN/VIII/2016 atas tindakan notaris LIS yang menjalankan amanat secara lisan untuk mengurus harta warisan bukan merupakan kualifikasi sebagai pelanggaran kode etik sebagaimana di atur dalam Pasal 4 ketentuan Kode Etik Notaris. Namun demikian, apabila mengacu pada ketentuan UUJN tindakan tersebut merupakan bentuk pelanggaran Pasal 52 UUJN yang menyatakan:

Notaris tidak diperkenankan membuat akta untuk diri sendiri, istri/suami, atau orang lain yang mempunyai hubungan kekeluargaan dengan Notaris baik karena perkawinan maupun 
hubungan darah dalam garis keturunan lurus ke bawah dan/atau ke atas tanpa pembatasan derajat, serta dalam garis ke samping sampai dengan derajat ketiga, serta menjadi pihak untuk diri sendiri, maupun dalam suatu kedudukan ataupun dengan perantaraan kuasa.

Berdasarkan ketentuan Pasal 52 UUJN di atas sangat jelas bahwa notaris tidak diperbolehkan membuat akta untuk pihak keluarga, maupun memiliki hubungan darah yang cukup jauh. Apabila notaris membuatkan akta bagi keluarganya, maka akta tersebut hanya memiliki kekuatan sebagai akta di bawah tangan. Hal ini sejalan dengan pendapat

Gunawan Djajaputra $^{15}$ dan Yurisa Martanti $^{16}$ yang pada intinya menegaskan bahwa notaris yang memiliki hubungan keluarga dilarang untuk mengurus pembuatan akta. Tidak ada notaris yang bisa menjadi pelaksana wasiat atau waris apalagi dilakukan secara lisan. Notaris tidak bisa

15) Wawancara dengan Dr. Gunawan Djajaputra, S.H., M.H., Op.Cit.

16) Wawancara dengan Dr. Yurisa Martanti, S.H., S.Pn. selaku Ketua Bidang Pendidikan dan Pelatihan Ikatan Notaris Indonesia, Jakarta, 18 April 2018. menjalankan amanat untuk mengurus harta waris, jika tidak ada yang meminta tidak boleh membuat sendiri. Seorang notaris tidak boleh membuatkan akta untuk anggota keluarganya.

Penulis berpendapat bahwa putusan Majelis Hakim MPW maupun MPPN, tidak melihat ketentuan Pasal 52 UUJN yang seharusnya menjadi bahan pertimbangan sebelum memutus dugaan pelanggaran terhadap UUJN. Dengan tidak melihat ketentuan Pasal 52 UUJN, Notaris LIS dinyatakan tidak terbukti karena dinilai tidak melanggar UUJN. Dengan demikian dapat dikatakan bahwa MPW maupun MPPN tidak cermat dalam melihat kasus yang dihadapi, padahal sudah menjadi kewenangan Majelis Pengawas Notaris untuk menjatuhkan sanksi terhadap Notaris yang melakukan pelanggaran.

Pelanggaran terhadap ketentuan Pasal 52 UUJN bukanlah pelanggaran kode etik. Kalaupun MPPN menyatakan bersalah melanggar ketentuan Pasal 52 UUJN, tidak ada sanksi bagi notaris namun hanya berakibat pada keabsahan akta yang dibuat menjadi akta di bawah 
tangan sebagaimana diatur

dalam Pasal 52 Ayat (3).

Berdasarkan uraian di atas, dapat diketahui bahwa kualifikasi tindakan notaris dapat dikatakan sebagai pelanggaran kode etik hanya diatur dalam ketentuan Pasal 4 Kode Etik Tahun 2015 diantaranya meliputi akta yang telah terlebih dahulu dipersiapkan oleh notaris lain sehingga notaris yang bersangkutan tinggal menandatangani; saling menjatuhkan antara notaris yang satu dengan yang lain; menggunakan jasa perantara seperti biro jasa dalam mencari klien; ketentuan mengenai pemasangan papan nama di depan atau di lingkungan kantor notaris, ditemukannya notaris yang membuat papan nama melebihi ukuran yang telah ditentukan. Persaingan tarif yang tidak sehat, dimana terdapat notaris yang memasang tarif yang sangat rendah untuk mendapatkan klien; melakukan publikasi atau promosi diri dengan mencantumkan nama dan jabatannya, seperti pengiriman karangan bunga pada suatu acara tertentu; menahan berkas seseorang dengan maksud memaksa orang membuat akta kepada notaris yang menahan berkasnya; mengirim minuta kepada klien untuk ditanda tangani oleh klien yang bersangkutan; dan membujuk klien membuat akta atau membujuk seseorang agar pindah dari notaris lain. Notaris yang melanggar ketentuan Pasal 52 UUJN bukanlah pelanggaran terhadap kode etik, namun melanggar UUJN akan tetapi dalam ketentuan Pasal 52 tersebut tidak ada sanksi bagi notaris namun hanya berakibat pada akta yang dibuatnya menjadi akta di bawah tangan.

UUJN dan Kode Etik menghendaki agar Notaris dalam menjalankan tugas jabatannya sebagai pejabat umum, selain harus tunduk pada UUJN juga harus taat pada Kode Etik serta harus bertanggungjawab terhadap masyarakat yang dilayaninya, organisasi profesi (Ikatan Notaris Indonesia atau INI) maupun terhadap negara. Dengan adanya hubungan ini maka terhadap Notaris yang mengabaikan keluhuran dari martabat jabatannya selain dapat dikenai sanksi moril, ditegur atau diberhentikan dari keanggotaan profesinya juga dapat diberhentikan dari jabatannya sebagai Notaris. Sepanjang apa yang sudah dilakukan oleh Notaris sudah sesuai dengan ketentuan 
perundang-undangan

khususnya UUJN dan tidak melanggar Kode Etik yang telah ditentukan, maka Majelis Pengawas tidak memperkenankan Notaris yang bersangkutan untuk memenuhi aparat penegak hukum walaupun hanya sebagai saksi. Dengan dibentuknya Majelis Kehomatan Notaris, diharapkan Notaris lebih profesional dalam menjalankan tugasnya. Hal ini dikarenakan eksistensi Majelis Kehormatan Notaris yang baru menurut peraturan perundang-undangan baik untuk tingkat daerah maupun tingkat pusat merupakan pengawas sekaligus pelindung serta mengayomi Notaris agar tetap menjalankan tugasnya sesuai dengan ketentuan hukum yang berlaku.

III. Penutup

\section{A. Kesimpulan}

Berdasarkan uraian pembahasan analisis di atas, maka penulis berkesimpulan sebagai berikut:

1. Jabatan notaris diatur UUJN yang merupakan produk hukum yang dimaksudkan untuk memberikan kepastian dan perlindungan hukum bagi Notaris dalam menjalankan profesinya sebagai pejabat pembuat akta otentik. Oleh karena itu di dalam UUJN maupun Kode Etik Notaris memuat aturan hukum yang salah satunya adalah bentuk perlindungan hukum bagi Notaris. Perlindungan hukum tehadap jabatan notaris atas dugaan pelanggaran kode etik dalam pengurusan harta waris tetap berhak mendapatkan perlindungan meskipun setelah diproses di Majelis Pengawas Notaris tidak terbukti melanggar kode etik. Mengacu pada Pasal 9 Ayat (7) Kode Etik Notaris, yang menyatakan bahwa apabila anggota yang bersangkutan tidak terbukti melakukan pelanggaran, maka anggota tersebut dipulihkan namanya dengan Surat Keputusan Dewan Kehormatan yang memeriksanya. Notaris tetap berhak mendapatkan perlindungan dalam setiap menjalankan tugasnya baik dalam kasus perdata maupun pidana sebagaimana diatur dalam UUJN dan Kode Etik Notaris.

2. Kualifikasi tindakan notaris dapat dikatakan sebagai pelanggaran kode 
etik hanya diatur dalam ketentuan Pasal 4 Kode Etik Tahun 2015. Notaris yang melanggar ketentuan Pasal 52 UUJN bukanlah pelanggaran terhadap kode etik, namun melanggar UUJN akan tetapi dalam ketentuan Pasal 52 ayat 3 hanya berakibat akta hanya mempunyai kekuatan pembuktian sebagai akta di bawah tangan apabila akta itu ditandatangani oleh penghadap, tanpa mengurangi kewajiban Notaris yang membuat akta itu untuk membayar biaya, ganti rugi, dan bunga kepada yang bersangkutan.

B. Saran

\begin{tabular}{lr}
\multicolumn{2}{c}{ Berdasarkan uraian } \\
kesimpulan di atas, maka \\
saran-saran yang & dapat \\
penulis kemukakan & adalah \\
sebagai berikut: & \\
1. Hendaknya & Majelis \\
Pengawas Notaris lebih \\
cermat dan teliti dalam \\
menangani r kasus \\
pelanggaran kode etik dan \\
pelanggaran UUJN karena \\
sudah $r$ menjadi \\
kewenangan \\
tanggungjawab Majelis \\
Pengawas Notaris.
\end{tabular}

2. Notaris hendaknya lebih teliti dalam menjalankan

\begin{abstract}
tugasnya dalam pembuatan akta karena ada larangan bagi notaris membuat akta atau dokumen kenotariatan yang masih dalam status hubungan keluarga.
\end{abstract}

IV. Daftar Pustaka

A. Buku

Anshori, Abdul Ghofur, Lembaga Kenotariatan Indonesia. (Yogyakarta: UUI Press, 2009).

Fuady, Munir. Profesi Mulia (Etika Profesi Hukum bagi Hakim, Jaksa, Advokat, Notaris, Kurator dan Pengurus). (Bandung: PT. Citra Aditya Bakti, 2005).

Hadjon, Philipus M. Perlindungan Hukum Bagi Rakyat Indonesia. (Surabaya: PT. Bina Ilmu, 1987).

Mamuji, Sri, et.al. Metode Penelitian dan Penulisan Hukum, (Jakarta: Badan Penelitian Penerbit Fakultas Hukum Universitas Indonesia, 2005), hal.13.

Marzuki, Peter Mahmud. Penelitian Hukum, cetakan ke-11, (Jakarta: Kencana, 2011), hal.35.

Soekanto, Soerjono dan Sri Mamudji. Penelitian Hukum Normatif: Suatu Tinjauan Singkat, (Jakarta: PT 
RajaGrafindo Persada, 2003), hal. 13.

Tobing,

G.H.S.

Lumban. Peraturan Jabatan

Notaris, Cetakan Ke-4,

(Notaris Reglement). (Jakarta:

Erlangga, 1996).

B. Peraturan

Perundang-

Undangan

Indonesia. Undang-Undang No.

2 Tahun 2014 Tentang

Perubahan Atas Undang-

Undang Nomor 30 Tahun

2004 tentang Jabatan

Notaris; (Lembaran Negara

Republik Indonesia Tahun

2014 Nomor 3; Tambahan

Lembaran Negara Republik

Indonesia Nomor 5491).

Perubahan Ketentuan Kode Etik

Notaris Kongres Luar Biasa

Ikatan Notaris Indonesia di

Banten pada tanggal 29-30

Mei 2015.

C. Makalah/Artikel/Internet

Sofyan, Syafran. "Perlindungan

Hukum Terhadap Profesi

Notaris", (On-Line),

http://www.indonesianotaryc

ommunity.com/perlindungan-

hukum-terhadap-profesi-

notaris/, (4 Maret 2018).

D. Wawancara

Djajaputra, Gunawan. Wawancara dengan dosen dan notaries. Gedung Blok M. Universitas
Tarumanagara, Jakarta, 25 April 2018.

Martanti, Yurisa. Wawancara dengan Ketua Bidang Pendidikan dan Pelatihan Ikatan Notaris Indonesia, Jakarta, 18 April 2018.

Wiryomartani, Edward S. Wawancara dengan Notaris/PPAT di Tangerang, 4 Mei 2018.

E. Kamus

Departemen Pendidikan Nasional, Kamus Besar Bahasa Indonesia. Edisi ke-3. (Jakarta: Balai Pustaka, 2002).

Poerwadarminta, W.J.S. Kamus

Umum Bahasa Indonesia. Cetakan IX, (Jakarta: Balai Pustaka, 1986).

Puspa, Yan Pramadya. Kamus Hukum, Edisi Lengkap, (Semarang: Aneka Ilmu).

F. Putusan

Salinan Putusan Nomor 03/MPPN/VIII/2016. 